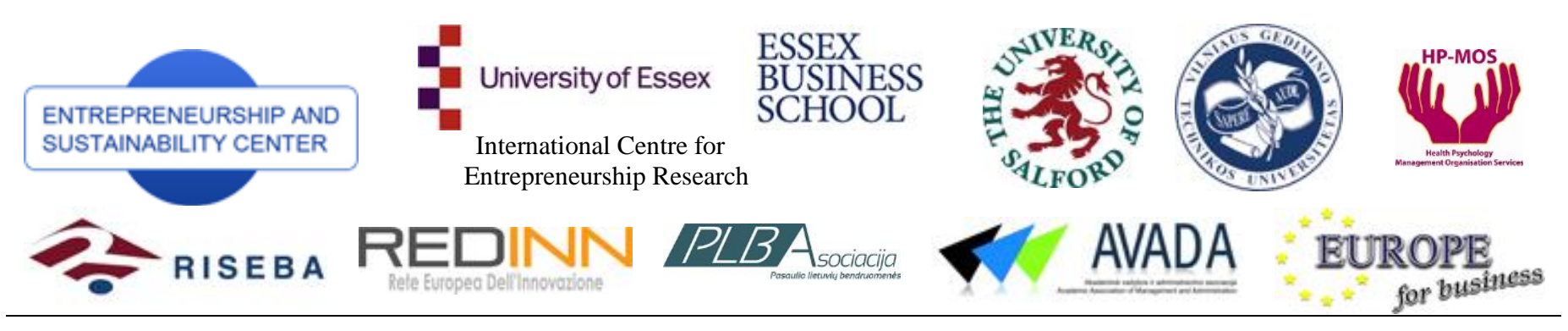

ENTREPRENEURSHIP AND SUSTAINABILITY ISSUES

ISSN 2345-0282 (online) http://jssidoi.org/jesi/aims-and-scope-of-research/

\title{
ACCOUNTING PRODUCTIVITY IN THE SECTORS OF ECONOMY: METHODOLOGICAL ASPECTS
}

\author{
Toma Lankauskienè \\ Vilnius Gediminas Technical University \\ Sauletekio al. 11, LT-10223 Vilnius, Lithuania \\ E-mail: toma.lankauskiene@gmail.com
}

Received 10 July 2014; accepted 20 August 2014

\begin{abstract}
Level of productivity is vital for each country striving develop sustainably. It appears that accounting of productivity requires additional attention of scientists. This paper is focused on the methods allowing to evaluate productivity in economy sectors. Scrutinized scientific literature proposes the following possible perceptions of productivity increase: as labour move from low to high productivity sectors, the process contributes to aggregate country's productivity growth, and causes further productivity increase in more productive sectors. After critical scientific literature review, conclusions about contemporary productivity methods and are being be provided.
\end{abstract}

Keywords: economic sectors' performance, productivity, aggregate productivity, economic growth, sustainable development.

Reference to this paper should be made as follows: Lankauskiené, T. 2014. Accounting productivity in the sectors of economy: methodological aspects, Entrepreneurship and Sustainability Issues 2(2): 98-106.

DOI: http://dx.doi.org/10.9770/jesi.2014.2.2(5)

JEL Classifications: $\mathrm{O} 40, \mathrm{O} 47$

\section{Introduction}

Sustainable development of countries and their economies' sectors is driven by array of factors (Mačiulis, Tvaronavičienè 2013; Baublys et al. 2014; Balitskiy et al. 2014; Caurkubule, Rubanovskis 2014; Dzemyda, Raudeliūnienè 2014; Fuschi, Tvaronavičienė 2014; Kaminskienè et al. 2014; Raudeliūnienè et al. 2014; Scaringelli 2014; Tarabkova 2014; Tvaronavičienè 2014; Tvaronavičienė et al 2014; Vasiliūnaitė 2014). Productivity is vitally import as driving force of sustainable development, which in own turn is affected by various factors (Mathur et al. 2013; Bonetto et al. 2014; Demir et al. 2014; Figurska 2014; GarškaitėMilvydiené, 2014; Ruza et al. 2014; Tvaronavičienè 2014, Wahl 2014). Researches, related to relevant economy structure and economic growth, generally named as structural economics, are in foreign rather common in scientific literature of development economics. This research area in Lithuania is relatively young and currently is intensively developing (e.g. Lankauskiené, Tvaronavičienè 2013; Lankauskienè, Tvaronavičienė 2014). In this paper attention is being focused to productivity measurement and accounting methods. This paper aims to systemize and group the methods evaluating productivity, which can reveal more precise picture of productivity in separately taken economy sectors. 


\section{Economy sectors' performance in structure of economy}

\subsection{Determinants of economy sectors' performance}

Based on the reform agenda agreed upon in Lisbon, enterprise and industrial policies require a detailed understanding of the competitive process at the level of individual industries and sectors (Peneder 2009; Figurska 2014; Tvaronavičienè 2014). Within this context, the current study on sectorial growth drivers aims to identify the major determinants, patterns and trends in European competitiveness from a distinctly sectorial perspective. The first part of this study investigated European sectorial competitiveness, assessing the relative strengths and weaknesses of European industries with respect to the various dimensions of performance, such as the growth of value added, employment, labour and multifactor productivity, profitability, international trade, and foreign direct investments (Peneder 2009; Tvaronavičienè 2014). Hereinafter, an investigation of the major determinants or 'drivers' of sectorial growth will be provided.

Sectorial performance is driven by a myriad of distinct sources. At present, no single, comprehensive theory exists which can explain the role of these elements within a jointly integrated economic model. However, many of them are the subject matter of different strands of economic research. Accordingly, this model is organized according to six groups of related factors: macroeconomic conditions, demand side factors, inputs to production, R \& D and innovation, market structure, and finally openness and barriers to trade (Peneder 2009). Figure 1 illustrates the six major dimensions of sectorial performance. First, macroeconomic conditions affect sectorial performance by defining the environment within which companies and industries operate.

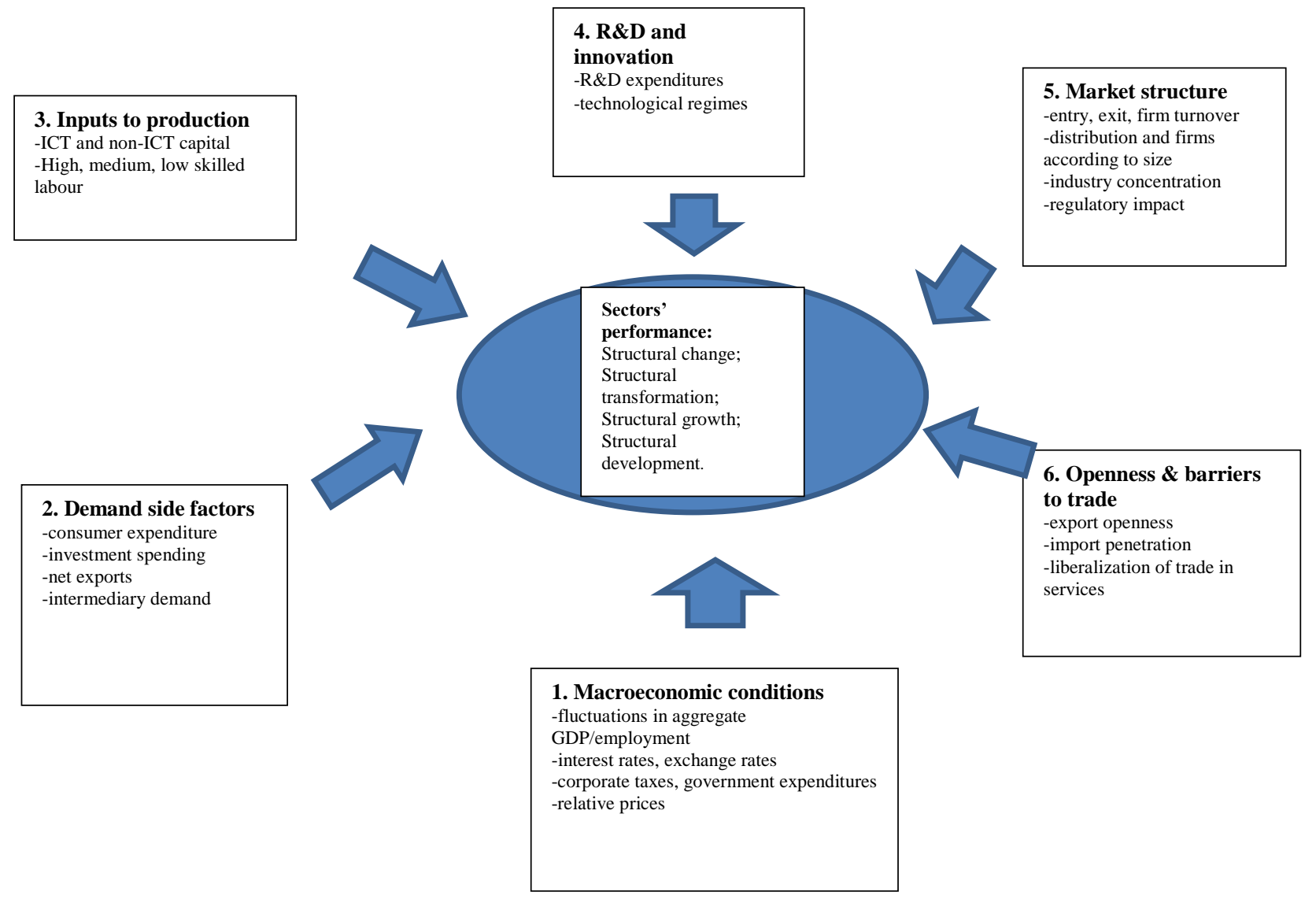

Fig 1. Stylized model of selected sectorial performance drivers

Source: complemented by author referring Peneder, M. 2009. Sectorial growth drivers and competitiveness in the European Union. European Commission, Enterprise and industry, European communities, 1-542 p. 


\subsection{Possible economy sectors' performance variations}

Economic growth can not be perceived without role of economic sectors, as economies are comprised of them. The following economic sectors' performance peculiarities in the structure of economy could be distinguished: structural change, structural transformation, structural growth, and structural development. It is important to mention that structural change and transformation are quite similar expressions, as well as structural growth and development (Lankauskienė, Tvaronavičiene 2013). Economic sectors' performance in the structure of economy most commonly is being defined as structural changes by foreign scientists (Lankauskienè, Tvaronavičienè 2013; Figurska 2014). Structural change is the central insight of development economics. Economic growth reflects in economic sectors' performance and entails structural change. Structural change, narrowly defined as the reallocation of labour across economy sectors, featured in the early literature on economic development by Kuznets (1966). As labour and the other resources move from traditional into modern economic activities, overall productivity rises and income expand. The nature and speed with which structural transformation takes place is considered one of the key factors that differentiate successful countries from unsuccessful ones. Therefore, the new structural economists argue that economy structures should be the starting point for comparative economic analysis and the design of appropriate policies. For the process of sustainable development elabouration, it is especially important for economy sectors to perform in a sustainable manner (Lankauskienè, Tvaronavičienė 2013; Litvaj, Poniščiaková 2014; Tvaronavičienė 2014). Economic sectors' sustainable performance manner is associated as a target at the development of knowledge based and innovation susceptible sectors, but not with exploiting non renewable natural resources (Tvaronavičiené, Lankauskienė 2013). Economic growth encompasses the growth of value added, created by economic sectors and their branches performance. Moreover, economy structure has to operate through all the possible capabilities of sustainability.

\section{Productivity phenomenon evaluation methods in the structure of economy}

Productivity most generally is perceived as a measure of output or value added per labour input (hour worked). But due to the economy sectors' performance, in the structure of economy this phenomenon gains more forms. Hereinafter different methods accounting productivity will be provided.

\subsection{Aggregate productivity growth accounting method}

What is the impact of structural change on productivity growth? In response to this question many authors use an empirical methodology designed to analyse such issues, often called 'shift-share analysis'. It has been used frequently by among others economic geographers, economic historians, industrial economists and trade analysts. Essentially, it is a purely descriptive technique that attempts to decompose the change of an aggregate into a structural component, reflecting changes in the composition of the aggregate, and changes within the individual units that make up the aggregate. As such it is closely related to analysis of variance. There are many versions of this methodology, the main difference being the choice of base year or 'weights': initial year, final year, some kind of 'average', linked, etc., and each version usually has its critics as well as defenders (Hurber, Mayerhofer 2006; Maroto-Sanchez, Cuadrado-Roura 2009; Jalava 2006; Van Ark, Hann 1997; Vries et al. 2011). The reason for this state of affairs is the well known result in index number theory that if, say, initial or final year weights are applied throughout in decomposition, a residual will occur necessarily. So what many versions of this methodology do is to try to reduce this residual as much as possible (Tanuwidjaja, Thangavelu 2007). Authors examine the effects of recent structural changes on the growth of labour productivity. The traditional assumption of the growth accounting literature is that structural change is an important source of growth and overall productivity improvements. The standard hypothesis assumes a surplus of labour in some (less productive) parts of the economy (such as agriculture), thus shifts towards higher productivity sectors (industry) are beneficial for aggregate productivity growth. Even within industry, shifts towards more productive branches should boost aggregate productivity. On the other hand, structural change may have a negative impact on aggregate productivity growth if labour shifts to industries with slower productivity growth. The 'structural bonus and burden' hypotheses were examined by the example of Asian economies by Timmer and Szirmai (2000), a large sample of OECD and developing countries (Fagerberg 2000), and more recently by Peneder and 
DG Employment for the USA, Japan and EU Member States (Peneder 2009). The overall developments regarding output, employment and productivity described above mask substantial structural changes within economies and their individual sectors. Structural changes reflect inter alia different speeds of restructuring and resulting efficiency gains or losses at branch level. The impact of structural change on aggregate productivity growth in is evaluated by the frequently applied shift-share analysis in analogy with Timmer and Szirmai (2000), Fagerberg (2000), Peneder (2003) and others. The shift-share analysis provides a convenient tool for investigating how aggregate growth is linked to differential growth of labour productivity at the sectorial level and to the reallocation of labour between industries. It is particularly useful for the analysis of productivity developments in countries where data limitations prevent us from using more sophisticated econometric approaches (Havlik 2005).

Using the same notation as presented in Peneder (2003), authors decompose the aggregate growth of labour productivity into three separate effects:

$$
\begin{aligned}
& \operatorname{growth}\left(L P_{T}\right)=\frac{L P_{T, f y}-L P_{T, b y}}{L P_{T, b y}}= \\
& \text { I:static.shift.effect II:dynamic.shift.effect } \\
& \frac{\sum_{i=1}^{n} L P_{i, b y} \cdot\left(S_{i, f y}-S_{i, b y}\right)+\sum_{i=1}^{n}\left(L P_{i, f y}-L P_{i, b y}\right) \cdot\left(S_{i, f y}-S_{i, b y}\right)+\sum_{i=1}^{n}\left(L P_{i, f y}-L P_{i, b y}\right) \cdot S_{i, b y}}{L P_{T, b y}}
\end{aligned}
$$

First, the structural component is calculated as the sum of relative changes in the allocation of labour across industries between the final year and the base year, weighted by the value of the sector's labour productivity in the base year. This component is called the static shift effect. It is positive/negative if industries with high levels of productivity (and usually also high capital intensity) attract more/less labour resources and hence increase/decrease their share of total employment. The standard structural bonus hypothesis of industrial growth postulates a positive relationship between structural change and economic growth as economies are upgrading from low- to higher-productivity industries. The structural bonus hypothesis thus corresponds to an expected positive contribution of the static shift effect to aggregate growth of labour productivity (Havlik 2005).

The structural bonus hypothesis:

$$
\sum_{i=1}^{n} L P_{i, b y}\left(S_{i, f y}-S_{i, b y}\right)>0
$$

Second, dynamic shift effects are captured by the sum of interactions of changes in employment shares and changes in labour productivity of individual sectors/industries. If industries increase both labour productivity and their share of total employment, the combined effect is a positive contribution to overall productivity growth. In other words, the interaction term becomes larger, the more labour resources move toward industries with fast productivity growth. The interaction effect is, however, negative if industries with fast growing labour productivity cannot maintain their shares in total employment. Thus, the interaction term can be used to evaluate Baumol's hypothesis of a structural burden of labour reallocation which predicts that employment shares shift away from progressive industries towards those with lower growth of labour productivity (Baumol 1967; Havlik 2005).

We would expect to confirm the validity of the structural burden hypothesis in the NMS due to the abovesketched shifts from industry to services (with lower productivity levels) at the macro level, and due to shifts from heavy (and capital-intensive) to light industries within manufacturing, respectively (Havlik 2005). 
The structural burden hypothesis:

$$
\sum_{i=1}^{n}\left(L P_{i, f y}-L P_{i, b y}\right)\left(S_{i, f y}-S_{i, b y}\right)<0
$$

Third, the 'within-growth' effect corresponds to growth in aggregate labour productivity under the assumption that no structural shifts in labour have ever taken place and each industry (sector) has maintained the same share in total employment as in the base year. Authors, however, recall that the frequently observed near equivalence of the within-growth effect and aggregate productivity growth cannot be used as evidence against differential growth between industries. Even in case all positive and negative structural effects net out, much variation in productivity growth can be present at the more detailed level of activities (Havlik 2005).

\subsection{Accelerations and decelerations in aggregate productivity growth evaluation method}

Recent studies of economic growth have moved from explaining average trends in long-term growth to study growth accelerations and decelerations, because of the great instability in growth rates within countries. Authors argue that the standard shift-share analysis is inadequate to measure the contribution of sectors to accelerations in productivity. Very few countries have experienced consistently high growth rates over long periods. Rather, the more typical pattern is that countries experience phases of growth, stagnation, or decline of varying length. A study of these separate periods seems more revealing for a study of the determinants of growth than a longperiod average (Pritchett 2000). This raises the natural question which sectors in the economy contribute most to accelerations and decelerations in growth. For example, Jones and Olken (2008) suggest that employment reallocation to more productive sectors lies behind accelerations and decelerations of growth in many developing countries. Because of missing sectorial data, they are unable to test this hypothesis. Authors provide empirical evidence on the significance of various sectors in generating aggregate productivity growth by introducing a novel shift-share analysis and by applying this method to a new sectorial database for 19 countries in Asia and Latin America, spanning the period from 1950 to 2005. Each sector can contribute to aggregate growth in two ways: by productivity growth within the sector (the within-effect) and by expanding its share in aggregate inputs (the between- or shift-effect). To measure these contributions authors modify a standard tool in an economic historians' tool-box: the shift-share analysis introduced by Fabricant (1942). The shift-share analysis is used in many studies to measure the contribution of structural change to aggregate growth. For example, it features prominently in the discussion about the extent of Britain's decline relative to Germany and the US since the end of the nineteenth century (Broadberry 1998). Unfortunately, the interpretation of results from the traditional shift-share method is not straightforward (Timmer, Vries 2008; Timmer, Vries 2007).

Authors propose two modifications to the traditional shift-share analysis, which make its results more useful. First, the standard method does not allow for disequilibria in factor markets in which average productivity differs from marginal productivity. Especially in early stages of development, the agricultural sector is characterized by wide-spread disguised unemployment (Broadberry 1998). Authors use estimates of the shadow price of labour to measure this wedge and adjust the shift share method accordingly. This adjustment increases the measured importance of structural change to growth. Second, the traditional method does not properly account for differences in productivity levels between sectors. For example, the expansion of a low-productive sector such as government services would show up as being positive for aggregate growth. Authors account for differences in productivity levels between sectors and derive more meaningful measures of the contribution of particular sectors to aggregate productivity growth. Authors find that resource reallocation is not the main driver of accelerations and decelerations in aggregate economic growth. Productivity improvements within sectors, in particular within manufacturing and market services, appear to be much more important for growth in Asia and Latin America since the 1950s (Timmer, Vries 2008; Timmer, Vries 2007).

Since long, the importance of sectorial development patterns for economic growth has been recognized. Changes in the sectorial composition of production and employment and their interaction with the pattern of productivity growth feature prominently. Technological change typically takes place at the level of industries and induces 
differential patterns of sectorial productivity growth. At the same time, changes in domestic demand and international trade patterns drive a process of structural transformation in which labour, capital and intermediate inputs are continuously relocated between firms, sectors and countries (Kuznets 1966; Chenery et al. 1986; Harberger 1998). One of the best documented patterns of structural change is the shift of labour and capital from production of primary goods to manufacturing and services. Another finding is that the level and growth rate of labour productivity in agriculture is considerably lower than in the rest of the economy (at least at low levels of income), reflecting differences in the nature of the production function, in investment opportunities and in the rate of technical change (Syrquin 1984; Crafts 1984). Together these findings suggest a potentially important, albeit temporary, role for resource allocation from lower to higher productive activities to boost aggregate productivity growth. This potential growth bonus was already identified in classical dual economy models such as Lewis (1954) and Fei and Ranis (1964). These models presumed that in early stages of development, agricultural labourers shift to the industrial sector without any reduction in total agricultural output. The existence of this source of inefficiency can be explained by the immobility of agricultural labour vis-a-vis the industrial sector caused by the discrepancy between private costs, approximated by the average product in agriculture, and social costs. Differences in the potential for structural change have featured prominently in explanations of differential growth within European countries in the post-World War II period (Temin 2002).

However, the quantification of its importance has been hampered by a clear methodology to measure the effect of structural change on aggregate productivity growth. The standard method to measure this is the shift-share decomposition originating from Fabricant (1942). This method is part of the standard tool kit of economic historians and used in many studies. One major problem of the traditional shift share method is the assumption that productivity growth within each sector is not affected by structural change. Clearly productivity growth rates are affected since, for example, productivity growth in agriculture is largely possible due to the employment reallocation to manufacturing and services. For example, labour productivity in South Korean agriculture increased 5\% annually during the period 1963-2005. It is not likely that this high growth rate could have been sustained when in 2005 still $63 \%$ of the population was working in agriculture, as in 1963. Broadberry (1998) argued that the shift-share analysis should be modified by assuming that the marginal productivity of workers leaving shrinking sectors is equal to zero. Although this adjustment overestimated the effect of sectorial expansions (Booth 2003), authors propose an extension and improvement of the traditional shift-share analysis in a similar direction without overstating sectorial employment reallocation.

Authors suggest the following modified shift-share analysis:

$$
\mathrm{P}^{\mathrm{T}}-\mathrm{P}_{\mathrm{i} \in \mathrm{K}, \mathrm{J}}=\sum_{\mathrm{i}}\left(\mathrm{P}_{\mathrm{i}}^{\mathrm{T}}-\mathrm{P}_{\mathrm{i}}^{\mathrm{O}}\right) * \mathrm{~S}_{\mathrm{i}}^{-}+\sum\left(\mathrm{S}_{\mathrm{i}}^{\mathrm{T}}-\mathrm{S}_{\mathrm{i}}^{\mathrm{O}}\right) *\left(\mathrm{P}^{-}-\mathrm{P}_{\mathrm{J}}^{-}\right)
$$

Where: $\quad \mathrm{P}$ being labour productivity, $\mathrm{S}$ i sectorial employment shares in the $\mathrm{i}$-th sector $(1, \ldots, 10), \mathrm{T}$ indicating the end of a period, 0 the beginning of a period, and a bar indicating period average.

The first term on the right hand side measures the contribution of within-sector productivity growth (intra effect). The second term on the right hand side measures the contribution of sectorial reallocation of employment to aggregate productivity growth (shift effect).

With average labour productivity in shrinking sectors $\mathrm{P}_{\mathrm{J}}^{-}=\frac{\sum_{i \in \mathrm{J}}\left(\mathrm{S}_{\mathrm{i}}^{\mathrm{T}}-\mathrm{S}_{\mathrm{i}}{ }^{\mathrm{O}}\right) * \mathrm{P}_{\mathrm{i}}^{-}}{\sum_{\mathrm{i} \in \mathrm{J}}\left(\mathrm{S}_{\mathrm{i}}^{\mathrm{T}}-\mathrm{S}_{\mathrm{i}}{ }^{\mathrm{O}}\right)}$

$\mathrm{J}$ the set of shrinking sectors, $\mathrm{K}$ the set of shrinking sectors.

The modified shift-share analysis decomposes growth in GDP per worker into improvements within industries and improvements due to the reallocation of labour across industries. In the decomposition, authors account for surplus labour. Furthermore, expanding sectors only contribute to productivity growth if their productivity level is higher than the economy's average (Timmer, Vries 2007, 2008). 


\section{Conclusions}

Productivity usually is perceived as a measure of output or value added per labour input (hour worked).

Analysis of relevant scientific literature in this research area let to reveal much more productivity measurement options. From one point of view it can be related to labour movement from low productivity to high productivity sectors and in such a manner contributing to aggregate country's productivity growth. And from another point of view productivity increase can be associated within sectors to capital accumulation, technological change, innovation, etc.

In the structure of economy, due to economic sectors' performance, productivity phenomenon can be accounted by different shift-share (decomposition) methods: aggregate productivity accounting method encompassing structural bonus, structural burden and within growth hypothesis; accelerations and decelerations in aggregate productivity growth evaluation method. Each of listed methods could be used ad hoc depending on the purpose of carried research. Hence, proper evaluating of productivity could provide possibilities of economy restructuring, which, in its turn would facilitate sustainable development and long-term competitiveness increase.

\section{References}

Balitskiy, S.; Bilan, Y.; Strielkowski, W. 2014. Energy security and economic growth in the European Union, Journal of Security and Sustainability Issues 4(2): 123-130. DOI: http://dx.doi.org/10.9770/jssi.2014.4.2(2)

Baublys J.; Miškinis V.; Konstantinavičiūtė I.; Lekavičius V. 2014. Aspirations for sustainability and global energy development trends, Journal of Security and Sustainability Issues 3(4): 17-26. DOI: http://dx.doi.org/10.9770/jssi.2014.3.4(2)

Baumol, W.J. 1967. Macroeconomics of unbalanced growth: the anatomy of urban crisis, The American Economic review 57: 415-426.

Bonetto, P.; Hoffmann, B.; Prause, G. 2014. Rise and fall of the Lyon silk cluster: a case study about entrepreneurial sustainability, Entrepreneurship and Sustainability Issues 2(1): 1-11. DOI: http://dx.doi.org/10.9770/jesi.2014.2(1)

Booth, A. 2003. The Broadberry-Crafts view and evidence: a reply, Econ Hist Rev 56:736-742.

Broadberry, SN.1998. How did USA and Germany overtake Britain?: a sectorial analysis of comparative productivity levels, 1870-1990, Econ His 58: 375-407.

Caurkubule, Ž.; Rubanovskis, A. 2014. Shadow economy as a obstacle to sustainable Economic development, Journal of Security and Sustainability Issues 4(2): 175-186. DOI: http://dx.doi.org/10.9770/jssi.2014.4.2(6)

Chenery, H.; Robinson, S.; Syrquin, M. 1986. Industrialization and growth: a comparative study. Oxford University press: New York.

Crafts, NFR. 1984. Patterns of development in nineteenth century Europe, Oxfor Economics Papers 36: 438-458.

Demir, E.; Marco Lau, Chi.K.; Bilgin, M.H. 2014. The impact of 2008 financial crisis on firm's productivity: evidence from Latvia, Lithuania and Romania, Journal of Security and Sustainability issues 3(4): 27-35. DOI: http://dx.doi.org/10.9770/jssi.2014.3.4(3)

Denison, EF. 1967. Why growth rates differ. Washington DC: Brookings.

Dzemyda, I.; Raudeliūnienè, J. 2014. Sustainable youth entrepreneurship in conditions of global economy toward energy security, Entrepreneurship and Sustainability Issues 1(4): 247-256. DOI: http://dx.doi.org/10.9770/jesi.2014.1.4(7)

Fabricant, S. 1942. Employment in manufacturing: New York.

Fagerber, J. 2000. Technological progress, structural change and productivity growth: a comparative study, Structural change and economic dynamics 11(4): 393-412.

Fei, JCH; Ranis, G. 1964. Development of the labour surplus economy. Irwin: Homewood. 
Fuschi, D.L.; Tvaronavičienè M. 2014. Sustainable development, Big Data and supervisory control: service quality in banking sector, Journal of Security and Sustainability Issues 3(3): 5-14. DOI: http://dx.doi.org/10.9770/jssi.2014.3.3(1)

Garškaitè-Milvydienè, K. 2014. Anti-crisis management of enterprises and possibilities of overcoming their critical condition, Journal of Entrepreneurship and Sustainability Issues 1(4): 187-203. DOI: http://dx.doi.org/10.9770/jesi.2014.1.4(1)

Harbeger, A.1998. A vision of the growth process, American Economic Revision 88:1-32.

Havlik, P. 2005. Structural change, productivity and employment in the new EU member states, the Vienna institute for international economic studies, Wiiw research reports 313 . Available on the Internet< http://www.ekof.bg.ac.rs/nastava/savremni_priv_sistemi/dec2006/structural\%20change\%20,peter\%20tr.pdf >.

Hurber, P.; Mayerhofer, P. 2006. Structural Change in the CENTROPE Region, Workshops proceedings of on workshops, No 9. Available on the Internet <www.oenb.at/.../Workshops/2006/Workshop-No.../ws_09_tcm16-42773.p... >.

Jalava, J. 2006. Production, primary, secondary and tertiary: Finnish growth and structural change, 1860-2004, Pellervo Economic Research Institute Working Papers 80: 27. ISBN 952-5594- 06-8 (PAP), ISBN 952-5594-07-6 (PDF), ISSN 1455-4623.

Jones, B.F.; Olken, B.A. 2008. The anatomy of start- stop growth. Rev Econ Stat.

Kaminskienè, N.; Žalènienè, I.; Tvaronavičienè, A. 2014. Bringing sustainability into dispute resolution processes, Journal of Security and Sustainability Issues 4(1): 69-77. DOI: http://dx.doi.org/10.9770/jssi.2014.4.1(6)

Kuznets, S. 1966. Modern economic growth: rate, structure and spread. Yale university press: London.

Lankauskienė, T.; Tvaronavičienė, M. 2012. Production factors and structural changes in economy sectors: genesis of theoretical approaches. ISI Conference proceedings "Contemporary issues in business, management and education", Vilnius, Lithuania. ISSN 20297963/ISBN 978-609-457-323-1. DOI:10.3846/cibme.2012.20

Lankauskienè, T.; Tvaronavičienè, M. 2013. Economic sector performance and growth: contemporary approaches in the sustainable development context, Intellectual economics 3(7): 355-374.

Lankauskienė, T.; Tvaronavičienė, M. 2014. Economy structure, productivity and economic growth: towards methodological perspective, 8th International Scientific Conference "Business and Management 2014" May 15-16, 2014, Vilnius, Lithuania, ISSN print 2029-4441/ ISSN online 2029-929X, ISBN print 978-609-457-652-2/ ISBN online 978-609-457-651-5. DOI: 10.3846/bm.2014.064

Lewis, W.A. 1954. Economic development with unlimited supplies of labor, Manchester Sch Econ Soc Stud 22: 139-191.

Litvaj, I.; Poniščiaková, O. 2014. Entrepreneurship and quality management, Entrepreneurship and Sustainability Issues 1(4): 204-209. DOI: http://dx.doi.org/10.9770/jesi.2014.1.4(2)

Figurska, I. 2014.Sustainable entrepreneurship: localization, acquiring and use of knowledge sources in competitive organization, Entrepreneurship and Sustainability Issues 1(4): 210-222. DOI: http://dx.doi.org/10.9770/jesi.2014.1.4(3)

Mačiulis, A.; Tvaronavičienè, M. 2013. Secure and sustainable development: Lithuania's new role in taking the Presidency of the EU, Journal of Security and Sustainability Issues 3(2): 5-13. DOI: http://dx.doi.org/10.9770/jssi.2013.3.2(1)

Maddison, A. 1987. Growth and slowdown in advanced capitalist economies: techniques of quantitative assessment, Journal of Economics Lit 25: 649-698.

Maroto-Sanchez, A.; Cuadrado-Roura, J.R. 2009. Is growth of services an obstacle to productivity growth? A comparative analysis, Structural Change and Economic Dynamics 20: 254-265.

Mathur, A.K; Roy, S.; Mitra, J. 2013. Toward sustainable development of economic sub-sectors: case of Indian sericulture, Journal of Security and Sustainability Issues 3(2): 15-30. DOI: http://dx.doi.org/10.9770/jssi.2013.3.2(2)

Peneder, M. 2003. Industrial structure and aggregate growth, Structural change and economic dynamics 14: 427-448.

Peneder, M. 2009. Sectoral growth drivers and competitiveness in the European Union. European Commission, Enterprise and industry, European communities, 1-542.

Pritchett, L. 2000. Understanding patterns of economic growth: searching for hills among plateaus, mountains and plains, World bank Econ Rev 14: 221-250. 
Pritchett, L. 2000. Understanding patterns of economic growth: searching for hills among plateaus, mountains and plains, World bank Econ Rev 14: 221-250.

Raudeliūnienè, J.; Tvaronavičienè, M.; Dzemyda, I. 2014. Towards economic security and sustainability: key success factors of sustainable entrepreneurship in conditions of global economy, Journal of Security and Sustainability Issues 3(4): 71-79. DOI: $\underline{\text { http://dx.doi.org/10.9770/jssi.2014.3.4(7) }}$

Ruza, O.; Lavrinenko, O.; Zelcs, R. 2014. Sustainable development of real estate market: impact of the micro and meso level factors, Journal of Security and Sustainability Issues 3(4): 45-60. DOI: http://dx.doi.org/10.9770/jssi.2014.3.4(5)

Scaringelli, M.A. 2014. Are the foreign controlled firms more environmentally sustainable than domestically controlled ones?, Journal of Security and Sustainability Issues 4(2): 131-146. DOI: http://dx.doi.org/10.9770/jssi.2014.4.2(3)

Syrquin, M. 1984. Resource allocation and productivity growth, in Syrquin, M.; Taylor, L.; Westphal, LE. (Eds.). Economic structure and performance. Essays in honour of Hollis B. Chenery. Academic Press: Orlando.

Tanuwidjaja, E.; Thangavelu, S. 2007. Structural Change and Productivity Growth in the Japanese Manufacturing Industry, Global economic review 36(4): 385-405.

Tarabkova, L. 2014. Model of motivating linked-up with education, Entrepreneurship and Sustainability Issues 2(1): 12-18. DOI: http://dx.doi.org/10.9770/jesi.2014.2.1(2)

Temin, P. 2002. The golden age of European growth reconsidered, Eur Rev Econ Hist 6:3-22.

Timmer, M. P.; Szirmai, A. 2000. Productivity growth in Asian manufacturing: the structural bonus hypothesis examined, Structural change and economic dynamics 11: 371-392.

Timmer, M.P.; Vries, G.J. 2007. A Cross-country Database for Sectoral Employment and Productivity in Asia and Latin America, 19502005.

Timmer, M.P.; Vries, G.J. 2008. Structural change and growth accelerations in Asia and Latin America: a new sectoral data set, Cliometrica. DOI 10.1007/s11698-008-0029-5.

Tvaronavičienè, M. 2014. If industrial sector development is sustainable: Lithuania compared to the EU, Entrepreneurship and Sustainability Issues 1(3): 134-142. DOI: http://dx.doi.org/10.9770/jesi.2014.1.3(2)

Tvaronavičienè, M.; Šimelytė, A., Lace, N. 2014. Sustainable development facets: exporting industrial sectors from inside, Journal of Security and Sustainability Issues 3(4): 37-44. DOI: http://dx.doi.org/10.9770/jssi.2014.3.4(4)

Van Ark, B.; Hann, J. 1997. The Delta- Model revisited: recent trends in the structural performance of the Dutch Economy, Research memorandum GD-38, Groginen growth and development centre.

Vasiliūnaite, R. 2014. Sustainable development: methodological approaches toward issues, Journal of Security and Sustainability Issues 3(3): 69-75. DOI: http://dx.doi.org/10.9770/jssi.2014.3.3(6)

Vries, G.J.; Erumban, A.A; Timmer, M.P; Voskoboynikov, I; Wu, H. X. 2011. Deconstructing the BRICs: Structural Transformation and Aggregate Productivity Growth, Research memorandum GD-121, Groginen growth and development centre, University of Groginen.

Wahl, M. 2014. Sustainable Entrepreneurship: The Wolf ButterBack Case, Entrepreneurship and Sustainability Issues 1(4): $223-229$. DOI: http://dx.doi.org/10.9770/jesi.2014.1.4(4)

Toma LANKAUSKIENE $\dot{E}$ is $\mathrm{PhD}$ in Economics at Vilnius Gediminas Technical University, Faculty of Business Management, Department of Economics and Management of Enterprises. Scientific research area: structural economics, development economics, sustainable development.

This is an open access journal and all published articles are licensed under a $\underline{\text { Creative Commons Attribution } 4.0 \text { International License }}$ 